Brit. J. vener. Dis. (1959), 35, 1.

\title{
THE ORIGIN OF SYPHILIS*
}

\author{
BY \\ L. W. HARRISON \\ London
}

In an opening address on the above subject to the Osler Club, London, on April 22, 1958, Prof. J. F. D. Shrewsbury advanced the (to me) novel suggestion that syphilis in its present form, which undoubtedly caused great alarm to health authorities in Europe in the late 90 s of the 15 th century, was due to the mutation about 1493 of a treponeme which had hitherto caused a milder form of treponematosis, such as Sibbens in Scotland and, under many other names, in Scandinavia and elsewhere. Thus, as I understood him, he gave $T$. pallidum a pedigree less than 500 years old with as parent a milder pathogen which had inhabited the world since pre-historic times.

The only other attempt at fixing a length of pedigree to $T$. pallidum which $I$ have been able to trace was that of H. V. Williams (1932), who, at the end of a long article describing syphilitic changes in bones found in American graves of date not later than A.D. 1300, said:

"Somewhere and at some time a non-pathogenic spiral organism acquired pathogenic properties and became Spirochaeta pallida. It seems likely that this event took place less than 10,000 years ago. An antiquity so slight as even 2,000 years would present no difficulty to modern bacteriologists. ..."

Personally, I find great difficulty in accepting Prof. Shrewsbury's thesis for the following reasons:

First, it seems to postulate the existence in the Old World before 1493 of a milder form of syphilis such as, he says, Sibbens and, I suppose, the Syphiloide of Jutland and the endemic syphilis of Bosnia Herzogovina and the Middle East of to-day.

I have not been able to trace any reference to Sibbens earlier than the 17th century. This occurred in the excellent article by E. Gilchrist in Essays and Observations of the Philosophical Society of Edinburgh, for the finding and a sight of which I am indebted to Dr. E. A. Underwood and Dr. F. N. L.

* Paper prepared for a discussion on "The Origin of Syphilis", at a meeting of the Osler Club, London, April 22, 1958. Received for publication November 17, 1958.
Poynter of the Wellcome Historical Medical Library. The essay was read in 1765 and published in 1771 ; it stated the belief that Sibbens was introduced to Scotland by the soldiers of Cromwell's army, and the author attributed the spread of the disease to the use of common table utensils, as was the case with the similar disease in Jutland when one spoon was used by the family at meals. Gilchrist gave what seemed to me very sensible directions for prevention of the spread of Sibbens.

Secondly, as it seemed to me, a much more likely reason for the severity of the contagious disease which alarmed the health authorities so much in the late 90 s of the 15th century was the soil in which $T$. pallidum was planted. In this regard I confess myself a strong believer in the theory that syphilis was brought to Europe from Hispaniola in March, 1493, by the sailors or/and Indian passengers returning with Columbus from his first voyage. The evidence for this rests largely on the accounts of Oviedo and of Las Casas, who were eye-witnesses of conditions in Hispaniola before the end of the 15th century, saw the effects of the disease when it could only have been caught from natives of that island, and agree in stating that the disease took a much more severe course in the Spaniards than in the natives.

Further, Las Casas, who had gained the confidence of the natives by his championship of their cause against the atrocities of the Spaniards, stated categorically that he had learnt from them that the disease was of great antiquity with them. Holcomb $(1934,1937,1939,1944,1945)$ may sneer at the evidence of these two witnesses by saying that at the time of the first voyage they were only in their 'teens -they were 18-19 years old at that time-but they were intelligent observers and on the spot in the later 90 s. They were opposed politically and it is difficult to believe that other than motives of truth caused Las Casas to write:•

"I took the trouble upon several occasions to interrogate the Indians of this island as to whether the disease was of great antiquity, and they answered 'Yes', that 
it dated from a period long before the advent of the Christians, the origin of it being beyond the memory of any man, and nobody can disbelieve this."

The fact that Las Casas went to Hispaniola first in 1498 and that the above was written some years later can hardly detract from the verity of such a broad general statement. Las Casas was old enough to appreciate that a new disease had arisen in Spain in the early 90 s of the 15 th century, since it is inconceivable that it would not be talked about in his hearing and he could not have failed to be interested in the fact that Spaniards infected in Hispaniola showed similar symptoms. It seems incredible that he did not receive proof on proof that the disease had existed in the island long before Columbus reached it.

There was, of course, a very good reason for the disease being mild in the natives of Hispaniola. Nobody who has worked with syphilis, even only in the clinical field, and still less no one who has taken an interest in experimental syphilis, can fail to be struck by the resistance to its effects which $T$. pallidum stimulates in the bodies of its victims. Volumes have been written on this and on its significance qua the continued presence of the parasite in the body. In those natives who were infected, $T$. pallidum must have been a permanent parasite, and the tissues must have contained abundant antibodies which must have been passed on to the offspring even when the latter were not infected. Equally, it is not difficult to imagine that such resistance persists for long after it has become no longer demonstrable by laboratory tests of the blood. Presumably, the treponeme which caused such relatively mild effects in the natives of Hispaniola and such severe effects in the virgin soil of the Spaniards' tissues was the same type as caused the changes in bones of persons buried not later than A.D. 1300 in different parts of America, North and South, which were judged by Williams (1932), by Means (1925), and by Cole (1951) and Cole, Harkin, Kraus, and Moritz (1955) to be undoubtedly tertiary syphilitic. These workers knew the pitfalls in judging the age of bones and in confusing the changes of tertiary syphilis with such as are caused by septic osteomyelitis or by arthritis deformans. One can perhaps rate the evidence of Cole and his colleagues all the higher, since Cole at any rate was (perhaps is) a believer in the existence of syphilis in the Old World from the earliest ages.

This brings me to the question whether syphilis originated in the Old World and reached America in pre-Columbian times via the Behring Straits, or whether the mutation to $T$. pallidum occurred in America.

As mentioned, I believe that the mutation occurred in America, though I should be quite happy if the evidence happened to persuade me that it did not, and I certainly do not think, as some of the opponents of the American origin theory seem to do, that those of the opposite opinion require examination by a psychiatrist.

It seems convenient here to state the reasons for my belief in the American origin of syphilis by stating the answers to the main points in the opponents' arguments, and here I should like to acknowledge with gratitude the help I have received from my friends, Dr. Herman Beerman (Philadelphia), Dr. P. Durel (Hôpital St. Lazare), and Dr. A. Cavaillon (President of the International Union against V.D.), who supplied me with literature which I should have had very great difficulty in finding for myself. I have already mentioned the valuable help given me over the antiquity of Sibbens by Dr. Underwood and Dr. Poynter, and will mention below invaluable evidence given me by the Director General, Archives of France, through the good offices of the French Embassy in London.

The proponents of the view that syphilis was prevalent in the Old World before Columbus's voyages have based their belief mainly on the following points:

(1) That authors from the most ancient times, European, Arabian, Chinese, Japanese, etc., have described diseases, chiefly of the skin and genitalia, which they said were typical of syphilis.

(2) That bones from pre-historic graves in the Old World, e.g. in Europe, Egypt, and Japan, showed typical signs of tertiary syphilis.

(3) That aneurysm was described by Greek and other writers hundreds of years before Columbus's time and that (Butler) aneurysm is always syphilitic.

(4) That, if syphilis had been endemic in Hispaniola, the sailors of the expedition would all have caught it, whereas, according to the evidence of Columbus, himself, his three crews enjoyed perfect health.

(5) That, admitting the fact of a pandemic of an alarming, contagious disease in the 1490 s, which caused edicts to be issued excluding the infected from a number of different European towns, it was a mere coincidence that Columbus returned from his first voyage in March, 1493. Some of these edicts, say the objectors to the theory of the American origin of syphilis, were issued so close to the time of Columbus's return that they could not have been stimulated by any pandemic started by the Columbus crews.

For evidence on the five points set out above, I have studied in the original papers by Sticker (1931) in Jadassohn's "Handbuch der Haut- und Geschlechtskrankheiten", by Bloch in D'Arcy Power and 
Keogh Murphy's “System of Syphilis" (1908), by Dohi (1923), and by a number of American writers, including Holcomb, Butler (1937a, b), Cole (1951), Cole and others (1955), Means (1925), and Williams (1932). Besides these I have had the advantage of receiving from Dr. Cavaillon a copy of a Paris decree and information concerning steps taken by a number of French authorities to prevent the spread of the disease.

To take the points set out above seriatim:

(1) That authors described in ancient times diseases in the Old World that were either typically syphilitic or strongly suggestive of syphilis. The impression that all these descriptions makes on me is reacted to by wonderment at the claims to diagnostic abilitiy made by these medical historians. Syphilis has been well-named The Great Imitator and, conversely, I know no skin manifestation described by these various authors which could not just as well have been non-syphilitic. For examples of non-syphilitic rashes which can look uncommonly like common syphilitic ones, I would mention only, pityriasis rosea, urticaria pigmentosa, generalized scabies, psoriasis, pemphigus vegetans, chicken pox, and keratodermia blennorrhagica. Every one of these I have known to be treated for syphilis.

A careful syphilologist, knowing the mistakes which have been made in the past, would not make a diagnosis of syphilis either on a picture or even on a clinical description, although the author did say that the lesions were typically syphilitic; yet many medical historians do claim this diagnostic acumen in the case of syphilis.

So much for skin manifestations. As for genital symptoms, I have not seen an illustration or read a description of a typical Hunterian chancre in any of these ancient writings. Chancroidal ulcerations are not, of course, syphilitic, nor are all phagedenic sores.

(2) That bones from pre-Columbian graves in the Old World have shown gummatous changes. On this point I am content to rely on the evidence of Virchow, Elliot Smith and Dawson, Keith, and others quoted by Sticker, by Bloch, and by others, that they were unable to find any undoubtedly syphilitic change in any of the thousands of pre-1493 bones they examined. It is interesting that Virchow should have found changes in the bones of bears of the cavedweller age similar to those possibly resembling gummatous changes in human bones buried in the same period, the changes being attributed by Virchow to arthritis deformans.

(3) On the question of the existence of aneurysm in ancient times in the Old World, one could argue at great length, but even if the articles that have been quoted by different historians in favour of their belief in the existence of syphilis in the Old World in ancient times related only to aneurysm of the aorta, and that has certainly not been the case, it is necessary only to show that not all aneurysms of the aorta are syphilitic to destroy all that kind of evidence. I expect that readers could quote. plenty of instances of non-syphilitic aneurysm of the aorta, but I will mention only two sets. Beerman, Schamberg, Nicholas, and Greenberg (1957) mention that Brindley and Stembridge (1956) had stated that, in 9,273 necropsies performed at Galveston, Texas, in the 62 years from 1892 to 1953 , there had been found 369 aortic aneurysms and that 54 per cent. of them were syphilitic. Beerman and others, in the same review of the literature, quoted a paper by Enselberg (1956) on aneurysm of the abdominal aorta, in which he said that syphilis was becoming a relatively uncommon cause of this condition.

So much for the positive evidence that has been cited by different historians of the pre-Columbian existence of syphilis in the Old World. I should like to quote here what may be a piece of negative evidence which I came across quite accidentally when reading Duggan's "Devil's Brood" (1957). In this book it is related that Henry II, King of England and Duke of Normandy, married Eleanor of Aquitaine in 1152 at the age of 18 (when he had already acquired a reputation as a lecherous person), and that between the date of that marriage and 1167 she bore him eight children none of whom died in infancy. The first did die at the age of 3 years, but all the others appear to have reached adult age and often well beyond. Henry was by no means a faithful husband and is reported to have consorted throughout his life with low-class ladies of easy virtue. One would have thought that, if syphilis had then been endemic in England or in France, where Henry spent a great part of his time, he would have caught it and passed it on to his wife; yet no suggestive gap is shown in that family history of eight children born in approximately 14 years.

(4) That, if the crews of Columbus's vessels had met syphilis for the first time in Hispaniola, they would surely have become riddled with the disease, especially if, according to one life of Columbus which I have read, there was a ration of four native girls to one sailor. First, I would say that infection of every man at once by sexual means was not inevitable, since the natives would mostly have caught their infections in infancy or childhood and might mostly have become no longer contagious from the sexual point of view. On the other hand, of course, some would be sexually contagious and others contagious 
by other than sexual means. Morison (1942), in his life of Columbus, supposes that the crews who returned to Spain having left Hispaniola on January 4, 1493, must have been in good health to have coped with the severe rigours of the return voyage, but that may well have been the case. Only a few might have been infected by that time and their infections might have been under control-symptomless though not extinguished-by native remedies. Also there were the Indians who returned with them.

Holcomb and other authors report, as evidence against the importation of syphilis by those who returned with Columbus to Spain in the early part of 1493, a note in the journal kept by Columbus for the information of Ferdinand and Isabella. The note, which was dated November 27, 1492, was translated by Duff (1936) from the book by Las Casas:

\footnotetext{
"For praise be to Our Lord, there has not yet been one among my crew sick in bed or even with so much as a headache, excepting an old man who was troubled with gravel which he has had all his life and who recovered after three days. What I say applies to all three ships."
}

This was written 3 months after the expedition had left Spain and after about 8 weeks' residence on that island with its hot muggy climate, and the crew of Columbus's ship said to have been riff raff. At the time when the note was written, one of the captains had been absent with his ship for about a week, on a search for gold. If, in the light of this evidence, one can believe such a note, then, as the first Duke of Wellington once said, .......

The note is in keeping with what Duff says about the shiftiness and evasiveness of Columbus.

"We are soon struck by the dishonesty of Columbus in 'faking' the days' runs in order that the crews should not know exactly where they were or how far from Spain", p. 89.

Another example of this failing is given on p. 135, where it is mentioned that in a letter to Santangel, who financed the expedition, Columbus said that the first voyage took 33 days, whereas it took 71 days.

It was clearly Columbus's policy to paint his expedition in the most glowing colours, particularly in view of the trouble he had in getting a backing for the enterprise. That is understandable but it is not evidence that his crews did not bring syphilis to Spain.

Whatever its origin, there can be no doubt that the disease to which Fracastoro (1530) gave the name syphilis did cause a great amount of perturbation amongst the authorities responsible for protecting the health of their communities, witness the various edicts, mostly excluding the infected, notably the decree of the Diet of Worms, August 7, 1495; the Arrêt du Parlement de Paris, March 6, 1497; that of Lyons, August 12, 1497; and that of Edinburgh decreed by James IV of Scotland, September 22, 1497.

Concerning these edicts, Holcomb (1934), made some play of the fact, as he stated it, that some of them were too close to the arrival of Columbus at Palos (March 15, 1493) after his first voyage to have been inspired by any epidemic started by the Columbus party. The only evidence to this effect that I find in Holcomb's paper is the following:

"In the city of Paris an edict was issued March 25th, 1493, or 10 days after the arrival of Columbus at Palos, or a month prior to his arrival at Barcelona. This edict directed all persons with grosse verrole to leave Paris on pain of being thrown into the river."

Having often found historians inaccurate in their dates, I am always rather suspicious when one is mentioned and, if it is important, try to verify it. Accordingly I wrote to my friend, Dr. Durel, asking him if he could trace such an edict in the Records of Paris; I also asked him if he could say when was the first time the term grosse vérole was used. Dr. Durel passed my inquiry to our mutual friend, Dr. Cavaillon, who has evidently made a profound study of the subject, and he very kindly gave me some information which seems very useful from the point of view of this argument. The first was that he had not encountered any Paris edict dated March 25, 1493, relating to grosse verrole, and that the earliest one relating to syphilis in Paris which he had found was an Arrêt du Parlement de Paris dated March 6, 1497. The English translation of this decree runs as follows:

\footnotetext{
"To-day the sixth March, since in this city of Paris
} there are many sick of a certain contagious disease, named 'la grosse vérole', which has become prevalent during the past two years. ..."

Incidentally this decree did not mention any such sanction as immersion in the river, but enjoined infected residents to keep to their houses, non-residents to return to their home towns if not indigent, and if indigent to go to St. Germain des Pres, to live in houses provided for them.

Thus there is a conflict of evidence between Holcomb and Cavaillon. If Holcomb was right in his view that there was an edict dated March 25, 1493 , concerning a disease known as grosse vérole and that this term referred to syphilis, that would be the end of the argument, because it would be impossible to believe that a disease the usual incubation period of which is about a month could have caused an epidemic calling for public health measures in 
Paris if it had been introduced to Europe by sailors landing at Palos, Spain, only 10 days earlier than the edict dealing with it. On the other hand, if this disease, apparently like that encountered by Columbus in Hispaniola, had been rampant in Europe, why had there been no earlier edict dealing with it? The points raised here are crucial and one cannot help wondering why Holcomb and those authors who were opposed to the theory that Columbus brought syphilis to the Old World did not worry at it until they had irrefutable evidence of such an edict as that quoted by Holcomb. As shown below, he cannot have examined it very critically, otherwise it would at once have been evident to him that the evidence was, to say the least, decidedly shaky.

I confess that at first I was inclined to leave this section of the subject without further challenge of the accuracy of Holcomb's statement than is contained in the counter-statement by Cavaillon; I was disinclined to ask friends to take further trouble in searching documents in the French archives. However, I sent the draft of this paper to a few friends, and amongst them, Lieut.-Gen. Sir W. P. MacArthur, whose experience and authority as a medical historian are internationally renowned, warned me of the weakness of an assumption that Holcomb's reference to an edict dated March 25, 1493, was either wrong or did not refer to syphilis simply because Cavaillon had not found any such edict or any in Paris relating to syphilis earlier than 1497.

Reluctantly, therefore, I resumed efforts to test the reliability of Holcomb's reference and, after some failures to get anybody to search in the Bibliothèque Nationale, Paris, at last managed to engage a learned agent to do so.

I asked the agent to trace Holcomb's reference to discover whether or not it was to an original document or derived from some author's treatise and, if the latter, its date of publication. Holcomb's reference, given in the body of his article in the U.S. Naval Medical Bulletin was:

"Ordonnances des rois de France de la troisième race, Vol. XX, p. 436". This was traced in the Bibliothèque Nationale, and the full title of the work, on p. 436 of which the alleged edict was printed, was found to be:

"Ordonnances des rois de France de la Troisième Race recueillées par ordre chronologique, vingtième volume contenant les ordonnances rendues depuis le mois d'avril 1486 jusqu'au mois de decembre 1497 par Monsieur le Marquis de Pastoret, Membre de l'Institut. Paris Imprimerie Nationale MDCCCXL."

Clearly this was the source of Holcomb's information, and, in view of what follows, it is important to note certain points which are not apparent in his article. The first is that his quotation is not from an original edict but from a treatise by the Marquis de Pastoret, published in 1840; between the end of the 15 th century and the early years of the 19th there could have been abundant chances of mistakes in dates, as indeed will be seen later in this article to have occurred. The second point is that Holcomb's paper gives one the impression that this was the first edict on grosse verrole, but the preamble to the edict shows that this was not so, and one might have thought that Holcomb would have used this fact to strengthen his argument; obviously, if there had been an edict on grosse vérole even earlier than March 25, 1493, Columbus's men could not have been the people responsible for this outbreak of grosse vérole. The translation of the title and of the preamble to the edict in question is:

"ORDERS CONCERNING THE CONTAGIOUS DISEASES AND FILTHS."(1) Although it has been published at sound of trumpet and by town crier in the public squares of Paris, so that nobody can pretend ignorance, that all persons suffering from grosse verrole $^{(2)}$ shall forthwith live outside the city ... under pain of death; nevertheless the said diseased persons, ignoring the said announcements, have returned from all parts, and hold converse with healthy persons, which is very dangerous for the people and the nobility at present in Paris.

(1) It is enjoined by the king and my lord the Provost of Paris, to all the said sufferers from the said disease etc., as, in effect, quoted by Holcomb.

(2) Footnote by the Marquis, to indicate this refers to "Mal de Naples".

The third point is that on the page (436) on which this edict was printed was a footnote, presumably by Pastoret as editor, which the further information below shows him to have been. It is under the mark (1) placed in the title of the edict. It appears to be an explanation of the inclusion of the edict in Pastoret's compilation. The translation of the note is:

"We think we may and even ought to insert here the ordinance concerning some contagious diseases and filths. M. IsAmbert has stated in his work: 'One has not been able to find', he says, 'the royal ordinance nor even the decree of Parliament cited by $\mathbf{M}$. Dulaure, under the date 6th March, p.469, third edition, which prescribes similar measures. If it had been only an ordinance of the Provost of Paris, it is worthy of remark that one has accorded him the power of pronouncing the penalty of death, he was therefore a legislator?' This order supposes that there was some other royal order. But one cannot help remarking as singular that this injunction dated 1493, whether it originated with the Provost of Paris or anyone else, speaks in precise terms of a disease which we habitually report as having originated from the Naples expedition, which did not take place until the year after. If the words were not so precise, one could come to 
believe that it dealt rather with leprosy. The significance which Turnebe and Saumaise and MeNAGE, after them, give to the word 'verole' makes this supposition more probable and the arrangements and edicts and ordinances on leprosy reported in the treatise on the Police would support this."

Fortunately, the questions which must arise in the minds of readers of the above note seem to be answered by a communication from the Department of the Director General, Archives of France, which was secured through the kind offices of the Scientific Office of the French Embassy, London, whose advice I had asked some time earlier on ways and means of searching the French Archives for the "Edict of March 25, 1493", quoted by Holcomb. The translation of the reply by the Director-General's Department to the Embassy's Scientific Office in London is as follows:

"In response to your letter of 21 st October, I have caused a search to be made for an edict concerning persons infected with grosse verrole, the edict supposed to have been promulgated in Paris on March 25, 1493.

"I have the honour to inform you that in all probability there is no edict concerning grosse vérole dated March 25, 1493. The text in question really bears the date June 25, 1498; it is to be found on Folio III $v$ of the Livre Bleu of the Chatelet de Paris preserved in the National Archives under the index Y 62 . I s a m be r t and $D$ e $\mathrm{c} \mathrm{u} \mathrm{s}$ y have published it from this source, in their compilation of ancient French laws, vol. XI, 1827 , p. 213 , but with the erroneous date, June 25 , 1493. The Marquis de Pastoret, editor of volume XX of the Ordonnances de France de la Troisième Race, has resorted to the former work to publish it again, p. 436, but by a fresh error, he has dated it March 25, 1493.

"In the first lines of the text in question there is an allusion to a preceding ordinance published to sound of trumpet in the streets of Paris. One may be sure that it deals with the ordinance of the Parliament of Paris dated March 6, 1497, which I. A. Dulaure cites in his Histoire Civile, Physique, et Morale de Paris, 3rd edition, 1825, vol. III, p. 469, and which Isambert admits his inability to find in the registers of the Parliament. This text is meantime preserved under the index X1A 1503 , pp. 74-75. The preamble of the ordinance mentioned that the grosse verrole had been current in the kingdom for two years, that the officers of the Courts of Justice in Paris had been enjoined in Parliament and invited to take some necessary measures but that they had not yet been able to advise because of difficulties which they had encountered. This text confirms, if it was necessary, the non-existence of an edict promulgated with effect from March 25, 1493."

So much for the edict alleged to be dated March 25,1493 ! Readers will, doubtless have noted, in the above letter, the reference to the edict of March 6,1497 , which was quoted by Cavaillon as the first in Paris relating to grosse vérole. Obviously, therefore, for March 25, 1493, one should read June 25, 1498, and should further understand that this was an ordinance made necessary by non-observance of the order of March 6, 1497.

Dr. Cavaillon cited edicts of other towns, including Edinburgh, which I have already mentioned. He said that the term grosse vérole was first used in France in 1495 to distinguish the disease from smallpox. He quoted a record of the town of Besançon in which it was mentioned that in April, 1496, ten persons were expelled from the town, being infected with "the Neapolitan disease", each receiving a florin, for maintenance I suppose. Besides these, other sums are mentioned as having been paid to doctors for the care of persons suffering, as it is stated, from "la gorre or disease of Naples". The edict of Lyons dated August 12, 1497, threatened that if anyone suffering from this disease did not report within 10 days his or her person should be apprehended and personal possessions publicly burnt.

On the question whether Charles VIII took syphilis to Naples, I do not think any time need be wasted. It seems to me probable that, in spite of treaties, Ferdinand and Isabella sent help to Naples in advance of the arrival of Charles, and this was nearly 2 years after the return of Columbus from his first voyage. One person can start an epidemic, and there were probably far more than one syphilitic in Naples by February 22, 1495, when Charles was welcomed there. His army left Naples on May 20, 1495 , and if by that time the city had not become riddled with syphilis, it would have been one of the wonders of the world. Apart from all this, camp followers, deserters, and vagrants of all kinds could have helped to distribute the disease.

Perhaps after all the above close (I hope) reasoning, one might be forgiven for indulging in a few speculations. The first was inspired by a presidential address to the Historical Section of the Royal Society of Medicine which was given by Sir Weldon Dalrymple-Champneys some time ago. In it he showed photographs of a number of Peruvian skulls, some of which had been trephined a number of times. It occurred to me that they might have been trephined because of multiple gummata. Syphilis in other ancient Peruvian bones has been proved by the American workers already quoted, and it is characteristic of syphilis that it tends to recur at the damaged spot; I gathered from the lecture that the ancient Peruvians liked to settle arguments with a club.

The second has hardly to do with the origin of syphilis except that the use of mercury has been used frequently in arguments about the birth-place of 
syphilis, almost, as it seemed to me, as if its use settled the diagnosis of lesions described in the literature as having occurred in the Old World long before 1493. Before the discovery of the modern precise tests of syphilis what was known as the "therapeutic test" was in common use; it consisted simply in watching the effect of anti-syphilitic remedies, including mercury, when the diagnosis was in doubt. It is not difficult to imagine that mercury was used for quite a number of nonsyphilitic complaints, because, in my view, it is a suppressor of tissue reaction. Anyone who has administered soluble salts of mercury intramuscularly to patients suffering from gonorrhoea and has seen its effect in rapidly reducing the discharge-almost to nothing in a week or 10 days - and yet has seen in the scanty remaining discharge swarms of gonococci in the now scanty pus cells, must believe that the mercury has acted only by suppressing the tissue reaction to the infection. Since seeing this effect in large numbers of cases of gonorrhoea, I have thought it possible that it might have influenced John Hunter to believe that gonorrhoea and syphilis were identical.

Dr. Durel, whose help I have acknowledged, has suggested to me, perhaps in a light-hearted mood, that if one could test mummies for antibodies to $T$. pallidum, and could have a hundred or so such specimens, one might perhaps settle this eternal question of the birth-place of syphilis.
REFERENCES

Beerman, H., Schamberg, I. L., Nicholas, L., and Greenberg, M. S., in collaboration with Guthe, T., and Hackett, C. J.' (1957). Arch. intern. Med., 99, 791 and 932.

Bloch, I. (1908). "A System of Syphilis", ed. D'Arcy Power and J. Keogh Murphy, vol. 1, pp. 1-39. Oxford Medical Publications, London.

Brindley, P., and Stembridge, V. A. (1956). Amer. J. Path., 32, 67.

Butler, C. S. (1937a). "Syphilis sive morbus humanus". Science Press, Brooklyn, New York.

(1937b). Privately printed reply to unfavourable review, in $J$. Amer. med. Ass. (1937), 109, 157, of Holcomb (1937).

Cole, H. N. (1951). A.M.A. Arch. Derm. Syph., 64, 12. Harkin, J. C., Kraus, B. S., and Moritz, A. R. (1955). Ibid., 71, 231 .

Dalrymple-Champneys, W. (1958). "Address to R.S.M., Section of the History of Medicine". Proc. roy. Soc. Med., 51, 385.

Dohi, K. (1923). "Beiträge 3 zur Geschichte der Syphilis in Ostasien". Nankodo, Tokyo.

Duff, C. (1936), "The Truth about Columbus and the Discovery of America", Grayson and Grayson, London.

Duggan, A. (1957). "Devil's Brood." Faber, London.

Enselberg, C. D. (1956). Cited by Brindley and Stembridge (1956)

Fracastoro, G. (1530). "Syphilis or the French Disease", trans. H. Wynne-Finch, 1935. Heinemann, London.

Gilchrist, E. (1771). Ess. Obs. phil. Soc. Edinb., vol. 3, p. 154. (read 1765.) [Wellcome Historical Medical Library.]

Holcomb, R. C. (1934). U.S. Nav. med. Bull., 32, 401

Holcomb, R. C. (1934). U.S. Nav. med. Bull., 32, 401. introd. C. S. Butler. Froben Press, New York.

- (1939). Mil. Surg., 84, 199.

(1944). Amer. J. Syph., 28, 511.

- (1945). "The Centaur of Alpha, Kappa, Kappa." Jan.

Keith, A. (1931). Quoted by Sticker, p. 390.

Las Casas, Fray Bartolomé de. "Historia general de las Indias." (Madrid, ed. D. J. Sanchon Rayon, 5 vols., 1875; Madrid, ed. 1886, p. 233). Cited by Duff (1936), Bloch (1908, p. 15), Morison (1942, p. 359).

Means, H. J. (1925). Amer. J. Roentgenol., 13, 359.

Morison, S. E. (1942). "Christopher Columbus, Admiral of the Ocean Sea." Oxford University Press.

Oviedo y Valdés, Fernandez de (1535). "Historia general y natural de las Indias." (Madrid, Real Academia de la Historia, 4 vols, 1851-55). Cited by Sticker (1931).

Smith, G., Elliot, and Dawson, W. R. (1924). "Egyptian Mummies." Allen and Unwin, London.

Sticker, G. (1931). In "Handbuch der Haut- und Geschlechtskrankheiten", ed. J. Jadassohn, vol, 23, p. 380. Springer, Berlin.

Virchow, A. (1858-96). Quoted by Sticker (1931).

Williams, H. V. (1932). Arch. Path. (Chicago), 13, 779. 